\title{
Arsenic Trioxide Induces Apoptosis and Incapacitates Proliferation and Invasive Properties of U87MG Glioblastoma Cells through a Possible NF- $\kappa$ B-Mediated Mechanism
}

\author{
Seyed H. Ghaffari*\&, Meysam Yousefi ${ }^{\star}$, Majid Zaki Dizaji, Majid Momeny, \\ Davood Bashash, Ali Zekri, Kamran Alimoghaddam, Ardeshir Ghavamzadeh
}

\begin{abstract}
Identification of novel therapeutics in glioblastoma remains crucial due to the devastating and infiltrative capacity of this malignancy. The current study was aimed to appraise effect of arsenic trioxide (ATO) in U87MG cells. The results demonstrated that ATO induced apoptosis and impeded proliferation of U87MG cells in a dosedependent manner and also inhibited classical NF- $\mathrm{KB}$ signaling pathway. ATO further upregulated expression of Bax as an important proapoptotic target of NF- $\mathrm{KB}$ and also inhibited mRNA expression of survivin, $\mathrm{c}-\mathrm{Myc}$ and hTERT and suppressed telomerase activity. Moreover, ATO significantly increased adhesion of U87MG cells and also diminished transcription of NF- $\mathrm{KB}$ down-stream targets involved in cell migration and invasion, including cathepsin B, uPA, MMP-2, MMP-9 and MMP-14 and suppressed proteolytic activity of cathepsin B, MMP-2 and MMP-9, demonstrating a possible mechanism of ATO effect on a well-known signaling in glioblastoma dissemination. Taken together, here we suggest that ATO inhibits survival and invasion of U87MG cells possibly through NF- $\kappa B$-mediated inhibition of survivin and telomerase activity and NF- $\kappa B$-dependent suppression of cathepsin B, MMP-2 and MMP-9.
\end{abstract}

Keywords: Glioblastoma - U87MG - arsenic trioxide - NF- $x \mathrm{~B}$

Asian Pac J Cancer Prev, 17 (3), 1553-1564

\section{Introduction}

Tumors of the central nervous system (CNS) are usually highly devastating because they are difficult to treat and may cause disability or death. Among these tumors, astrocytic gliomas pose particular challenges because of being the most common intracranial malignant tumors in humans, tendency toward malignancy, rate of infiltration, and the lack of effective therapy (Rao, 2003). Gliomas are classified from low- to high-grades (grades I-IV). Grade IV, also known as glioblastoma multiforme (GBM), is among the most lethal, highly invasive and least effectively-treated solid tumors in human. The main hallmark of GBM is tumor cell detachment and dissemination which trammels the current treatment strategies including radiation, chemotherapy and surgical resection (Nakada et al., 2007). Therefore, devising more efficacious curative remedies that target tumor cell spread and invasion in GBM remains of main priority.

Nuclear factor kappa B (NF- $\mathrm{B}$ ) plays a key role in the control of oncogenesis, tumor progression and chemoresistance of various types of malignancies as well as GBM (Zanotto-Filho et al., 2011; Westhoff et al., 2013). NF- $x B$ is formed by homo or heterodimers comprising members of the Rel protein family (p50/p105, p52/p100, p65, c-Rel and RelB). In non-stimulated cells, the members of this family form inactive cytoplasmic complexes by interacting with inhibitory proteins (IкB). Upon stimulation by different stimuli, IкBs are phosphorylated by IкB kinase (IKK) complex, thus releasing the active NF- $\mathrm{KB}$, which is translocated into nucleus and binds to DNA sequences in gene promoters and modulates the expression of a plethora of genes involved in all hallmarks of cancer including cell proliferation, evasion from apoptosis, immortality, and cell invasion (Baud and Karin, 2009). The relation between $\mathrm{NF}-\kappa \mathrm{B}$ activation and evasion from apoptosis in cancer cells is frequently reported (Baud and Karin, 2009). In addition, it has been demonstrated that NF- $\kappa \mathrm{B}$ has a key role in up-regulation of the antiapoptotic proteins, $\mathrm{Bcl}-2$, Bfl-1 and Bcl-w, as well as the downregulation of the pro-apoptotic proteins Bax and Bad (Cao et al., 2013). On the other hand, inhibition of NF- $x \mathrm{~B}$ is correlated with decreased expression of known anti-apoptotic genes (Bharti et al., 2003).

Survivin is one of the most important cancer-specific proteins identified to date and classified as a member of inhibitor of apoptosis protein (IAP) family (Ryan et al., 2009). It has been demonstrated that survivin is involved 
in a variety of cell processes including angiogenesis, cell invasion and metastasis, cell proliferation and inhibition of programmed cell demise (Conway et al., 2003; Li, 2005). These processes are carried out through different mediators. Importantly it has been shown that survivin stimulates telomerase activity which in turn impedes shortening of telomeres and subsequently gives the cancer cells the ability to proliferate indefinitely (Endoh et al., 2005a). An accumulating body of evidences highlights that survivin-dependent induction of telomerase mainly occurs through stimulatory effect of transcription factor c-Myc (Cerni, 2000; Wojtyla et al., 2011). The ability of c-Myc to induce the transcriptional activation of hTERT, has been shown to be increased in survivin gene transfectant cells (Endoh et al., 2005b). Given the critical functions of survivin in multistage tumorigenesis and its its key role in apoptosis and proliferation, therapeutic disabling of survivin is currently attracting considerable attention as a new pharmacological target for anti-cancer therapies, so that the translation of these findings to the clinic is currently ongoing with numerous phase I/II clinical trials targeting in progress (Ryan et al., 2009).

Tumor invasion consists of several discrete steps which finally leads to tumor cell interaction with extracellular matrix (ECM) ligands and destruction of the matrix by release of proteolytic enzymes, and subsequent migration of the tumor cells through the area of destruction (Ware et al., 2003). In this regard, downstream targets of NF- $\kappa$ B have the most known roles in glioma invasion. Urokinase plasminogen activator (uPA), which is activated by lysosomal protease cathepsin $\mathrm{B}$, has been thought to play a cardinal role in invasion of the tumor cell through ECM remodeling through activation of respective proteases (Guo et al., 2002). Of the most important uPA-activated proteases involved in ECM digestion, by far the most is known about the role of matrix metalloproteases (MMPs). It has been reported that high-grade human gliomas, including GBMs, highly express MMPs, whereas noninvasive low-grade gliomas and normal brain tissues do not (Ware et al., 2003). The members of the MMP family most central in glioma invasiveness are MMP-2 (72 KD gelatinase A) and MMP-9 (92 KD gelatinase B) (Wang et al., 2003). In fact, the determinant roles of $\mathrm{NF}-\kappa \mathrm{B}$ in triggering tumor invasion have been thought to be through the induction of MMP-2, MMP-9, and uPA. Moreover, MMP-2 has been shown to be activated by an integral plasma membrane-bound protease termed membrane-type 1 MMP (MT1-MMP, MMP14) (Ware et al., 2003). MMP-14 is upregulated in human gliomas and serves to concentrate the MMP-2 activity at the cell surface, presumably to facilitate ECM destruction and thus glioma invasion (Ware et al., 2003). Thus, therapeutically quelling expression/activity of the mentioned MMPs and their upstream mediators, Cathepsin B and uPA, seems an excellent opportunity in order to disrupt the proteolytic cascade and subsequently, tumor cell invasion.

Arsenic trioxide $\left(\mathrm{As}_{2} \mathrm{O}_{3}, \mathrm{ATO}\right)$ is used as a first and second line therapy for the treatment of both newlydiagnosed and relapsed patients with all-trans-retinoic acid (ATRA)-refractory acute promyelocytic leukemia (APL) (Lo Coco et al., 1999; Tallman, 2001). ATO causes differentiation in APL cells through degradation of chimeric PML-RAR $\alpha$ proteins and subsequently relieving from the negative repression of retinoid signal transduction (Sanz et al., 2005). This function seems to be responsible for the unique therapeutic effect of ATO in APL cells. Moreover, the other mechanisms through which ATO suppresses tumor cells include induction of programmed cell demise, suppression of cell growth and proliferation, impeding angiogenesis and hindering tumor cell invasion and metastasis (Jing et al., 1999; Miller et al., 2002; Wei et al., 2005; Momeny et al., 2010b). A plethora of evidences highlights that ATO is an efficacious drug against many other types of human cancers (Siu et al., 2002; Vuky et al., 2002; Yu et al., 2007; Morales et al., 2008; Pettersson et al., 2009; Liu et al., 2012). In this regard, it is of great importance to use this therapeutic agent for the treatment of various brain cancers including GBM (Cohen et al., 2013). In the present study, we aimed to investigate effects of ATO on proliferation, programmed cell death, cell invasion and cell migration, telomerase activity, and gene expression and activities of some key proteins involved in molecular biology of GBM and find possible molecular mechanisms for anti-neoplastic effects of ATO in U87MG cell line.

\section{Materials and Methods}

\section{Cell culture and ATO treatment}

The human glioblastoma cell line U87MG was purchased from Pasteur Institute of Iran (Tehran, Iran) and grown in RPMI 1640 medium (Invitrogen) supplemented with $10 \%$ fetal bovine serum (FBS), in $5 \% \mathrm{CO} 2$ at $37^{\circ} \mathrm{C}$. For ATO treatment, a relevant amount of stock solution (0.5 mM in RPMI 1640) of ATO (Sina Darou, Tehran, Iran) was prepared and then diluted by culture medium to get the desired concentrations (1-5 $\mu \mathrm{M})$. Thereafter, U87MG cells were incubated with the mentioned concentrations of ATO for 48, 72 and $96 \mathrm{~h}$.

\section{Microculture tetrazolium test (MTT)}

Microculture tetrazolium test (MTT) assay was used to assess the inhibitory effect of ATO on viability of U87MG cells. For this, seeded cells were plated in 96-well plates at density of 10,000 cells/200 $\mu 1$ PRMI in each well and then, exposed with $0,1,2,3,4$ and $5 \mu \mathrm{M}$ of ATO for 48 , 72 and $96 \mathrm{~h}$. then, the media were replaced by $100 \mu \mathrm{l}$ of $0.5 \mathrm{mg} / \mathrm{ml}$ MTT solution and after $3 \mathrm{~h}$, the MTT solutions were replaced with DMSO and the color absorbance was read at wavelength of $578 \mathrm{~nm}$ in an ELISA reader. The percentage cell viability was calculated as $(\%)=($ ODexp / ODcon) $\times 100$, where ODexp and ODcon are the optical densities of exposed and control cells, respectively.

\section{BrdU cell proliferation assay}

The suppressive effects of ATO on DNA synthesis (which is proportional to cell proliferation) was measured using a colorimetric bromodeoxyuridine (BrdU)based Cell Proliferation ELISA kit (Roche Molecular Biochemicals, Mannheim, Germany). Briefly, U87MG cells were seeded in 96-well plates (at a density of 10,000 cells/100 $\mu \mathrm{l} /$ well) and treated with $0,1,2,3,4$ and $5 \mu \mathrm{M}$ of 
$\mathrm{As}_{2} \mathrm{O}_{3}$ Induces Apoptosis and Abrogates Proliferation and Invasivion of U87MG Glioblastoma Cells - NF- $\mathrm{KB}$ Involvement

ATO for $48 \mathrm{~h}$, which is the clinical time interval for ATO and have significant effects on U87MG cell line, obtained from MTT results. Then, the treated cells were incubated with $10 \mu \mathrm{l}$ of $\mathrm{BrdU}$ solution at $37^{\circ} \mathrm{C}$ for $8 \mathrm{~h}$ followed by fixation and DNA denaturation using $200 \mu 1$ of Fix Denat solution provided with the kit. Then the fixed cells were incubated with peroxidase-conjugated anti-BrdU antibody at room temperature for $1 \mathrm{~h}$, and finally the cultures were exposed to $100 \mu \mathrm{l}$ of substrate tetramethyl benzidine for 30 min at room temperature. To stop the peroxidase reaction, $25 \mu \mathrm{l}$ of $1 \mathrm{M} \mathrm{H}_{2} \mathrm{SO}_{4}$ was applied and the samples were read at $450 \mathrm{~nm}$ in an ELISA reader.

\section{Cell-matrix adhesion assay}

After treatment of U87MG cells for $48 \mathrm{~h}$ with the concentrations of ATO as above, the cells at a density of $10,000 \mathrm{cells} /$ well/ were plated in 96 -well microtiter plate coated with type I collagen $(100 \mathrm{mg} / \mathrm{ml}$ in a well) (Sigma, USA) and incubated for $30 \mathrm{~min}$. Nonspecific binding was blocked by incubation with $2 \%$ BSA in PBS for $2 \mathrm{~h}$ at room temperature. Thereafter, non-adherent cells were removed by PBS washes and adherent cells were fixed by ethanol. Following staining with $0.1 \%$ crystal violet, fixed cells were lysed using $0.2 \%$ Triton X-100 and the absorbance was measured at $550 \mathrm{~nm}$.

\section{Measurement of MMP-2 and MMP-9 activity by gelatin zymography}

To monitor the effect of ATO on activity of MMP-2 and MMP-9,gelatin zymography was applied according to the previously described method (Hawkes et al., 2010). First, equal amounts of proteins from each conditioned medium were fractionated by SDS-PAGE on $8 \%$ polyacrylamide gels containing $2 \mathrm{mg} / \mathrm{ml}$ gelatin $\mathrm{A}$ and gelatin $\mathrm{B}$ as substrates of MMP-2 and MMP-9 respectively. After electrophoresis, the polyacrylamide gels were rinsed in $2.5 \%$ Triton $\mathrm{X}-100(3 \times 30 \mathrm{~min})$ and then rinsed in an incubation buffer at $37^{\circ} \mathrm{C}$ for $5-8 \mathrm{~h}$ which is necessary for MMP-2 and MMP-9 renaturation and activity. Thereafter, the gels were applied to staining with Coomassie Brilliant Blue $(0.5 \%)$ and destained with a buffer containing Tris$\mathrm{HCl}(50 \mathrm{mM})$ and $\mathrm{CaCl} 2(5 \mathrm{mM})$. To quantify MMP-2 and MMP-9 zymograms, the gels were scanned and the band intensities were analyzed by Multi-Analyst software (Bio-Rad Laboratories, Hercules, CA, USA).

\section{Cathepsin B activity assay}

To appraise the effect of ATO on the proteolytic activity of cathepsin B in the medium of U87MG cells, the cathepsin B activity assay kit (Biovision Research Products, Mountain View, California, USA) was used as the manufacturer's instructions. Briefly, equal amounts of proteins from conditioned media of each sample were incubated with $50 \mu \mathrm{l}$ of reaction buffer and $2 \mu \mathrm{l}$ of a specific synthetic substrate of cathepsin B on a 96-well plate at $37^{\circ} \mathrm{C}$ for $2 \mathrm{~h}$. The substrate contains amino-4trifluoromethyl coumarin, which is released because of cathepsin B activity. After reading the samples in a fluorescence spectrophotometer (Varian Australia Pty Ltd., Mulgrave, Australia) with a $400 \mathrm{~nm}$ excitation filter and a $505 \mathrm{~nm}$ emission filter, the inhibition rate of cathepsin
$\mathrm{B}$ activity was obtained by comparing the fluorescent units of ATO-treated samples with the control group and the percentage activity was calculated as $(\%)=$ RFUexp / RFUcon $\times 100$, where RFUexp and RFUcon are the relative fluorescent units of exposed and control cells, respectively.

\section{Apoptosis assay}

For the detection of apoptosis induced by ATO, a double staining kit with Hoechst 33342 and propidium iodide (PI) was used (Invitrogen). After treatment of U87MG cell line with the desired concentration of ATO for $48 \mathrm{~h}$, the cells were harvested and washed in a cold PBS and the cell density was adjusted to $0.5 \times 10^{6}$ cells $/ \mathrm{ml}$ in PBS. Then $1 \mu 1$ of the Hoechst 33342 stock solution (5.0 $\mathrm{mg} / \mathrm{ml}$ solution in water) and $1 \mu \mathrm{l}$ of the PI stock solution $(1.0 \mathrm{mg} / \mathrm{ml}$ solution in water) were added to each $1 \mathrm{ml}$ of cell suspension for $15 \mathrm{~min}$, the stained cells were evaluated by a flow cytometry instrument (Partec PasIII, Germany), using excitation/emission $\sim 350 / 461$ and $\sim 535 / 617 \mathrm{~nm}$ for Hoechst 33342 and PI, respectively. The data was analyzed using FlowMax software.

\section{Caspase-3 enzymatic activity assay}

To investigate the change in caspase- 3 activity caused by ATO in U87MG cells, a colorimetric caspase- 3 activity assay was carried out according to the kit's protocol (Sigma). First, the cells were treated with the desired concentrations of ATO in $5 \% \mathrm{CO}_{2}$ at $37^{\circ} \mathrm{C}$ for $48 \mathrm{~h}$. Following centrifugation at $600 \mathrm{X} \mathrm{g}$ for $5 \mathrm{~min}$, the cell pellets were lysed, and the lysates were centrifuged at $20,000 \mathrm{Xg}$ for $10 \mathrm{~min}$. Five micrograms of the supernatant was incubated with $85 \mu \mathrm{l}$ of assay buffer plus $10 \mu \mathrm{l}$ of caspase-3 substrate acetyl-Asp-Glu-Val-Asp p-nitroanilide (Ac-DEVD-pNA) in a 96 -well plate at $37^{\circ} \mathrm{C}$ for $3 \mathrm{~h}$. Plates were read at wavelength of $405 \mathrm{~nm}$ on a Microplate Reader Model 550 (Bio-Rad, Richmond, CA, USA).

\section{Cell-based NF-xB phosphorylation measurement by ELISA}

The effect of ATO on NF- $\mathrm{BB}$ phosphorylation was measured by Cellular Activation of Signaling ELISA (CASE Kit, Super Array Bioscience, Frederick, Maryland, USA). U87MG cells were plated in 96-well plates at a density of 10,000 cells/well/200 ml RPMI medium. After treatment with ATO for $48 \mathrm{~h}$ at in incubator, the cells were fixed in $8 \%$ formaldehyde in PBS solution and then incubated with primary and secondary antibodies, followed by an exposure to developing and stop solutions provided with the kit. After normalization with the relative cell number obtained by a cell staining buffer at $578 \mathrm{~nm}$, the ratio of phosphorylated $\mathrm{NF}-\kappa \mathrm{B}$ to total $\mathrm{NF}-x \mathrm{~B}$ was obtained at $450 \mathrm{~nm}$.

\section{Measurement of telomerase activity by TRAP assay}

To investigate the effect of ATO on enzymatic activity of telomerase in U87MG cells, a telomeric repeat amplification protocol (TRAP) assay was performed by Telo TAGGG telomerase PCR ELISA kit (Roche diagnostics GmbH, Manheim, Germany). First, the U87MG cells were treated with the desired concentration 
of ATO for $48 \mathrm{~h}$ and then, the cells were lysed in lysis buffer and subjected to protein extraction. Then equal aliquots of proteins were used for TRAP assay. After 30 cycles of PCR amplification, $10 \mu \mathrm{l}$ of the amplified telomerase products obtained in these assays were visualized on $8 \%$ PAGE, and the ladder was detected by staining with silver nitrate (Sigma). The gel image was analyzed using Multi-Analyst software (Bio-Rad Laboratories, Hercules, CA, USA), and the telomerase activity was calculated as the ratio of intensity of telomerase ladders to the intensity of the 36-bp internal control standard. Percentage of inhibition was calculated by comparing telomerase activity of ATOtreated cells with telomerase activity of the control.

Analysis of gene expression by quantitative real-time PCR

For performing real-time PCR, first the U87MG cells were treated with the concentrations of ATO and after $48 \mathrm{~h}$, RNA was extracted by Fast Pure RNA kit (Takara Bio Inc., Otsu, Japan) from the cultured cells and quantified by a Nanodrop instrument (Nanodrop ND-1000 Technologies, Wilmington, Delaware, USA). Then, $1 \mu \mathrm{g}$ of RNA from each sample was applied to reverse transcription using the Prime Script RT reagent kit (Takara Bio Inc). Realtime PCR was performed with a light cycler instrument (Roche Diagnostics, Germany) using SYBR Premix Ex Taq technology (Takara Bio Inc.). A total volume of 20 $\mu 1$, which contains $10 \mu 1$ SYBR Green master mix, $2 \mu 1$ of cDNA samples, $0.5 \mu 1$ of forward and reverse primers (10 pmol) and $7 \mu 1$ of nuclease-free water (Qiagen, Hilden,
Germany), were added into each capillary tube. Thermal cycling conditions were an initial activation step of $30 \mathrm{~s}$ at $95^{\circ} \mathrm{C}$ followed by 40 cycles including a denaturation step of $5 \mathrm{~s}$ at $95^{\circ} \mathrm{C}$ and a combined annealing/extension step of $20 \mathrm{~s}$ at $60^{\circ} \mathrm{C}$. Melting curves were analyzed to validate single $\mathrm{PCR}$ product of each primer. Hypoxanthine phosphoribosyl transferase1 (HPRT1) was amplified as internal control and the fold change in relative expression of each target mRNA was calculated on the basis of comparative $\mathrm{Ct}\left({ }^{2-\Delta \Delta} \mathrm{Ct}\right)$ method. The sequences of primers are listed in Table 1.

\section{Statistical analysis}

All the experiments in this work were performed in triplicate and the results were expressed as mean \pm standard deviation (SD). The statistical significance of differences throughout this study was calculated by Student's t-test and by one-way variance analysis and $\mathrm{p}<0.05$ was considered as significant.

\section{Results}

ATO inhibits viability and proliferation of U87MG cells in a concentration-dependent manner

MTT assay was performed to assess viability of U87MG cells after treatment with ATO for $48 \mathrm{~h}$. The results demonstrate that ATO significantly decreased the viability of U87MG cells in a dose-dependent manner (Figure 1). Treatment with concentrations 2, 3, 4 and

Table 1. Nucleotide Sequences of the Primers Used for Real-time RT-PCR

\begin{tabular}{|c|c|c|c|c|}
\hline Gene & Accession number & Forward primer $\left(5^{\prime}-3^{\prime}\right)$ & Reverse primer (5'-3') & Size \\
\hline HPRT & NM_000194 & TGGACAGGACTGAACGTCTTG & CCAGCAGGTCAGCAAAGAATTTA & 111 \\
\hline Bax & NM_138761 & CGAGAGGTCTTTTTCCGAGTG & GTGGGCGTCCCAAAGTAGG & 242 \\
\hline Bfl-1 & NM_004049 & TACAGGCTGGCTCAGGACTAT & CGCAACATTTTGTAGCACTCTG & 96 \\
\hline $\mathrm{Bcl}-2$ & NM_000633 & CGGTGGGGTCATGTGTGTG & CGGTTCAGGTACTCAGTCATCC & 90 \\
\hline Bcl-xl & NM_138578 & GAGCTGGTGGTTGACTTTCTC & TCCATCTCCGATTCAGTCCCT & \\
\hline Caspase-3 & NM_032991 & ATGGAAGCGAATCAATGGACTC & CTGTACCAGACCGAGATGTCA & 138 \\
\hline c-Myc & NM_002467 & CCACAGCAAACCTCCTCACAG & GCAGGATAGTCCTTCCGAGTG & 105 \\
\hline hTERT & NM_198253 & TGACACCTCACCTCACCCAC & CACTGTCTTCCGCAAGTTCAC & 95 \\
\hline IKK1 & NM_001278 & AAGTTGAACCATGCCAATGTTGT & TCTCCTCCAGAACAGTATTCCAT & 107 \\
\hline IKK2 & 001556 & CАССАТССАСАССТАСССТG & CTTATCGGGGATCAACGCCAG & 136 \\
\hline NEMO & NM_001099856 & CTTCCAAGAATACGACAACCACA & CGGAACGGTCTCCATCACAAT & 187 \\
\hline Survivin & NM_001168 & CCAGATGACGACCCCATAGAG & TTGTTGGTTTCCTTTGCAATTTT & 152 \\
\hline STAT3 & NM_139276 & ATCACGCCTTCTACAGACTGC & CATCCTGGAGATTCTCTACCACT & 176 \\
\hline $\mathrm{P} 21$ & NM_000389 & CCTGTCACTGTCTTGTACCCT & GCGTTTGGAGTGGTAGAAATCT & 130 \\
\hline MMP-2 & NM_004530 & CTTCCAAGTCTGGAGCGATGT & TACCGTCAAAGGGGTATCCAT & 119 \\
\hline MMP-9 & NM_004994 & GGGACGCAGACATCGTCATC & TCGTCATCGTCGAAATGGGC & 139 \\
\hline MMP-14 & NM_004995 & GAAGCCTGGCTACAGCAATATG & TGCAAGCCGTAAAACTTCTGC & 119 \\
\hline $\mathrm{uPA}$ & NM_002658 & TCAAAAACCTGCTATGAGGGGA & GGGCATGGTACGTTTGCTG & 121 \\
\hline uPAR & NM_002659 & TATTCCCGAAGCCGTTACCTC & TCGTTGCATTTGGTGGTGTTG & 275 \\
\hline Cathepsin B & NM_000100 & CTGTCGGATGAGCTGGTCAAC & TCGGTAAACATAACTCTCTGGGG & 152 \\
\hline NHE1 & NM_003047 & GGAGTGTCTGATAGCTGGCGA & TCCTCAGGATTTTGCGGATCT & 233 \\
\hline CA9 & NM_001216 & GTCTCGCTTGGAAGAAATCG & TAGAGGGTGTGGAGCTGCTTA & 201 \\
\hline
\end{tabular}


$\mathrm{As}_{2} \mathrm{O}_{3}$ Induces Apoptosis and Abrogates Proliferation and Invasivion of U87MG Glioblastoma Cells - NF- $\mathrm{\kappa B}$ Involvement

$5 \mu \mathrm{M}$ of ATO for $48 \mathrm{~h}$ reduced viability of the U87MG cells to $89.9 \%, 87.4 \%(\mathrm{p}<0.05), 82.2 \%(\mathrm{p}<0.05)$ and $78.1 \%(\mathrm{p}<0.01)$ compared to control. Also ATO inhibited viability of U87MG cells in a dose dependent manner after treatment for 72 and $96 \mathrm{~h}$ (data not shown). To assess the effect of ATO on DNA synthesis U87MG cells, a colorimetric BrdU proliferation assay was carried out as well. As shown in Figure 1, treatment with concentrations 2, 3, 4 and $5 \mu \mathrm{M}$ of ATO for $48 \mathrm{~h}$ inhibited proliferation of U87MG cells to $83.38 \%, 76.49 \%$ ( $\mathrm{p}<0.05), 67.62 \%$ $(\mathrm{p}<0.01)$ and $63 \%(\mathrm{p}<0.01)$.

\section{ATO strengthens adhesion of U87MG cells}

To evaluate the effect of ATO on adhesiveness of U87MG glioblastoma cells, a cell-matrix adhesion assay was carried out. Figure 2 demonstrates that different concentrations of ATO $(1,2,3$ and $4 \mu \mathrm{M})$ after $48 \mathrm{~h}$ increased adhesion of U87MG cells by $7 \%$, $49.3 \%(\mathrm{p}<0.05), 78.2 \%(\mathrm{p}<0.01)$ and $78.4 \%(\mathrm{p}<0.01)$, respectively.

\section{ATO reduces activity of MMP-2, MMP-9 and extracellular cathepsin B in U87MG cells}

Gelatinolytic activity of both MMP-2 and MMP-9 were inhibited in U87MG cell line after treatment with ATO for $48 \mathrm{~h}$. As shown in Figure 3, the inhibition rates in gelatinolytic activity of MMP-2 were $21.9 \%(\mathrm{p}<0.05)$, $25.1 \%(\mathrm{p}<0.05)$ and $40 \%(\mathrm{p}<0.01)$ for concentrations 2 , 3 and $4 \mu \mathrm{M}$ of ATO, while the inhibition rates for MMP-9 were $35.9 \%(p<0.01), 52.7 \%(p<0.01)$ and $66 \%(p<0.001)$ for the mentioned concentrations of ATO, respectively (Figure 3).

Moreover, Figure 4 demonstrates that treatment of the U87MG cell line with ATO for $48 \mathrm{~h}$ resulted in a dose-dependently decreased activity of cathepsin B, the upstream target of MMP-2 and MMP-9. The rates

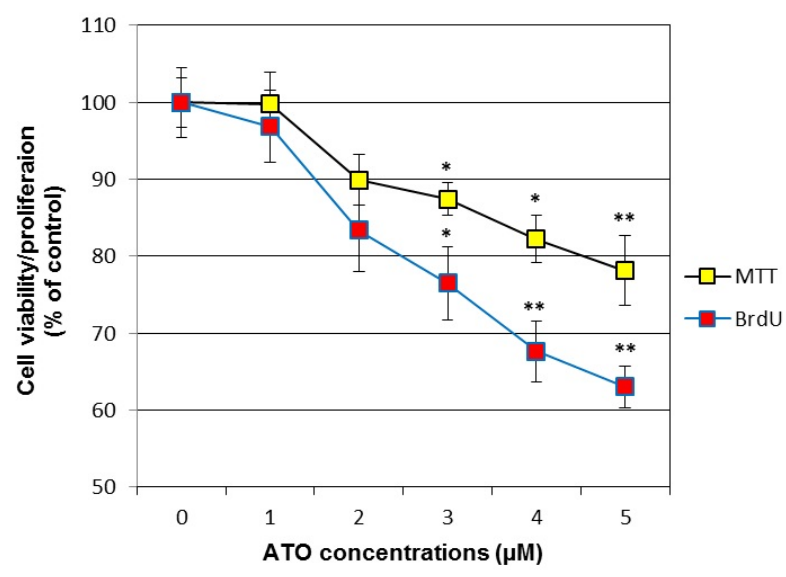

Figure 1. Evaluation of ATO Effect on the Viability and Proliferation of Human Glioblastoma U87MG Cells using MTT and BrdU Assays, Respectively. U87MG cells were treated with 1, 2, 3, 4 and $5 \mu \mathrm{M}$ of ATO for 48 $\mathrm{h}$. The viabilities were determined as percent compared to the controls. ATO inhibits proliferative properties of U87MG cells in a concentration-dependent manner. The results are presented as mean \pm SD from three independent experiments of reduction in cathepsin $\mathrm{B}$ activity were $12.3 \%, 19.2 \%$ $(\mathrm{p}<0.05), 22.6 \%(\mathrm{p}<0.01)$ and $25.1 \%(\mathrm{p}<0.01)$ for concentrations $1,2,3$ and $4 \mu \mathrm{M}$, respectively.

ATO induces apoptosis and stimulates caspase-3 activity in U87MG cells

Flow cytometry was used to investigate the effect of ATO on apoptosis induction in U87MG cells. As shown in

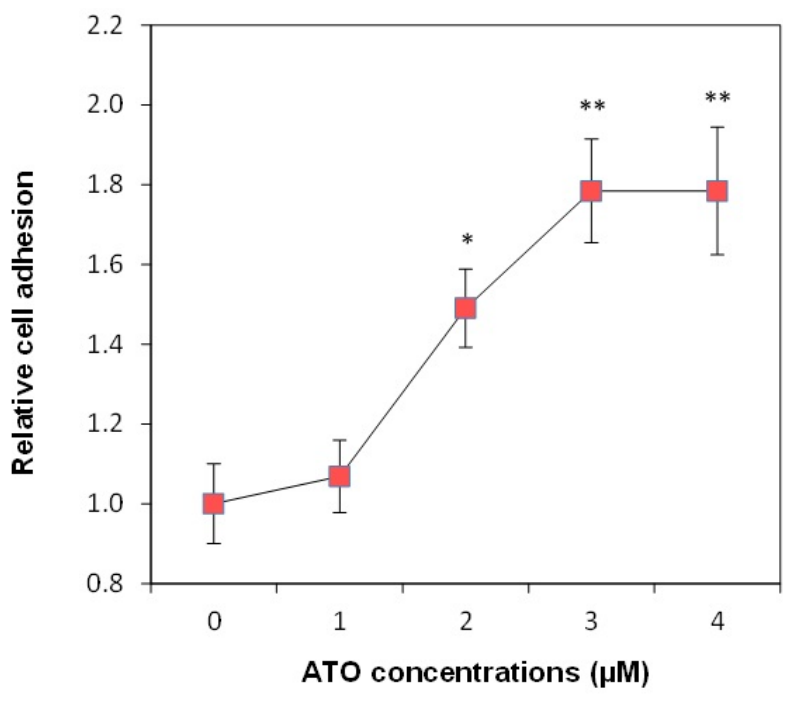

Figure 2. Effect of ATO on the Adhesion of U87MG Cells. The ATO-treated U87MG cells were plated in 96well microtiter plate coated with type I collagen (Sigma, USA) and their matrix-binding ability was measured as explained in section materials and methods. The adhesion of U87MG cells were increased by 7\%, 49.3\% ( $\mathrm{p}<0.05)$, $78.2 \%(\mathrm{p}<0.01)$ and $78.4 \%(\mathrm{p}<0.01)$ after treatment with $1,2,3$ and $4 \mu \mathrm{M}$ of ATO for $48 \mathrm{~h} . *: \mathrm{p}<0.05$ and $* *: \mathrm{p}<0.01$

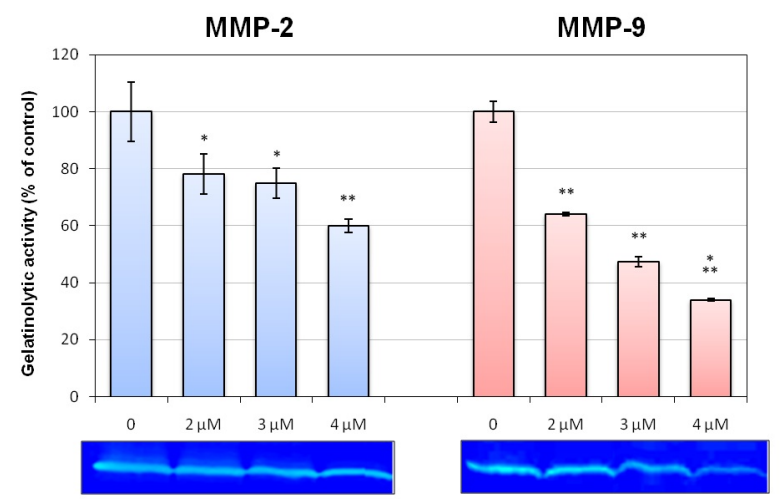

Figure 3. Inhibition of MMP-2 and MMP-9 Activity by ATO in U87MG Cells. The intensities of clear bands demonstrate the gelatinolytic activities of MMP-2 and MMP-9 against the blue background of the stained gelatin, and were analyzed by Multi-Analyst software (Bio-Rad Laboratories, Hercules, CA, USA). ATO at concentrations 2, 3 and $4 \mu \mathrm{M}$ inhibited gelatinolytic activity of MMP-2 by $21.9 \%(\mathrm{p}<0.05), 25.1 \%(\mathrm{p}<0.05)$ and $40 \%(\mathrm{p}<0.01)$ and MMP-9 by $35.9 \%(\mathrm{p}<0.01), 52.7 \%(\mathrm{p}<0.01)$ and $66 \%(\mathrm{p}<0.001)$, respectively. The values are given as mean \pm SD compared with the control $(*: \mathrm{p}<0.05, * *: \mathrm{p}$ $<0.01$ and $* * *: \mathrm{p}<0.001)$ 
Seyed $H$ Ghaffari et al

Figure 5,ATO in concentration 1,2,3 and $4 \mu \mathrm{M}$ increases apoptosis in U87MG cells by $8.1 \%$ (not significant), $9.1 \%(\mathrm{p}<0.05), 12.5 \%(\mathrm{p}<0.05)$ and $14.7 \%(\mathrm{p}<0.05)$, respectively. On the other hand, ATO dose-dependently stimulated activity of caspase-3 (Figure 6). Although this stimulation was not significant in case of 1 and $2 \mu \mathrm{M}$ of ATO, for higher concentrations $(3,4$ and $5 \mu \mathrm{M})$ this stimulation was statistically significant $(18.4 \%, 23.9 \%$ and $29.8 \%$ respectively, $\mathrm{p}<0.05)$.

ATO diminishes NF-xB phosphorylation in U87MG cells

As shown in Figure 7, the phosphorylation of NF- $x$ B, which is proportional to its activity, was not significantly changed after $48 \mathrm{~h}$ treatment with concentrations 1 and $2 \mu \mathrm{M}$ of ATO (11.6\% increase and $9.1 \%$ decrease, respectively, not significant); however, ATO diminished the activity of NF- $x$ B by $26.3 \%(\mathrm{p}<0.05)$ and $40.5 \%$ $(\mathrm{p}<0.01)$ at concentrations 3 and $4 \mu \mathrm{M}$, respectively.

ATO inhibits reverse-transcriptase activity of telomerase in U87MG cells

Effect of ATO on telomerase activity was determined with TRAP assay. The results illustrate that treatment of U87MG cells with ATO inhibits telomerase activity in a concentration-dependent manner (Figure 8); this observation is in line with the results from effect of ATO on transcriptional expression of hTERT. As illustrated in Figure 8, ATO at concentrations 1, 2, 3, 4 and $5 \mu \mathrm{M}$ for 48 $\mathrm{h}$ reduced the enzymatic activity of telomerase to $96.8 \%$, $87.9 \%, 71.33 \%(\mathrm{p}<0.05), 50.2 \%(\mathrm{p}<0.01)$ and $35.44 \%$ $(\mathrm{p}<0.01)$, respectively.

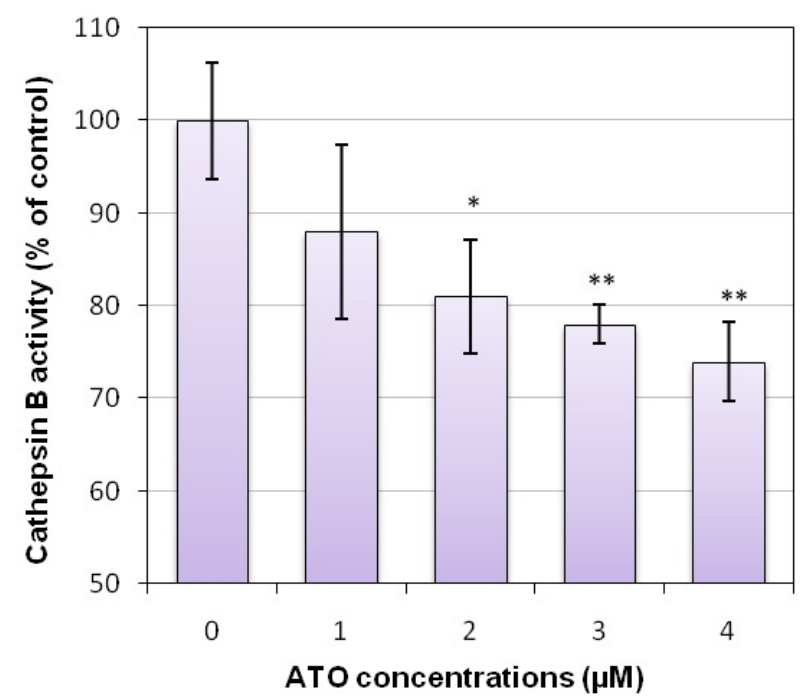

Figure 4. Evaluation of ATO Effect on Proteolytic Activity of Extracellular Cathepsin B Secreted from U87MG Cell Line. Equal amounts of proteins from conditioned media of ATO-treated U87MG cells were subjected to the synthetic substrate sequence arginine-arginine labeled with amino-4-trifluoromethyl coumarin (AFC). The R-R-AFC substrate is cleaved by cathepsin B to release AFC, which is fluorometerically detected by $400 \mathrm{~nm}$ excitation and $505 \mathrm{~nm}$ emission filters. ATO at concentrations 1,2,3 and $4 \mu \mathrm{M}$ inhibited activity of cathepsin by $12.3 \%, 19.2(\mathrm{p}<0.05), 22.6(\mathrm{p}<0.05)$ and $25.1 \%(\mathrm{p}<0.05)$, respectively
ATO down-regulates transcriptional expression of IKK2, Survivin, $c-M y c$ and hTERT and up-regulates $m R N A$ expression of NEMO and STAT3

Regarding that NF- $x \mathrm{~B}$ phosphorylation was
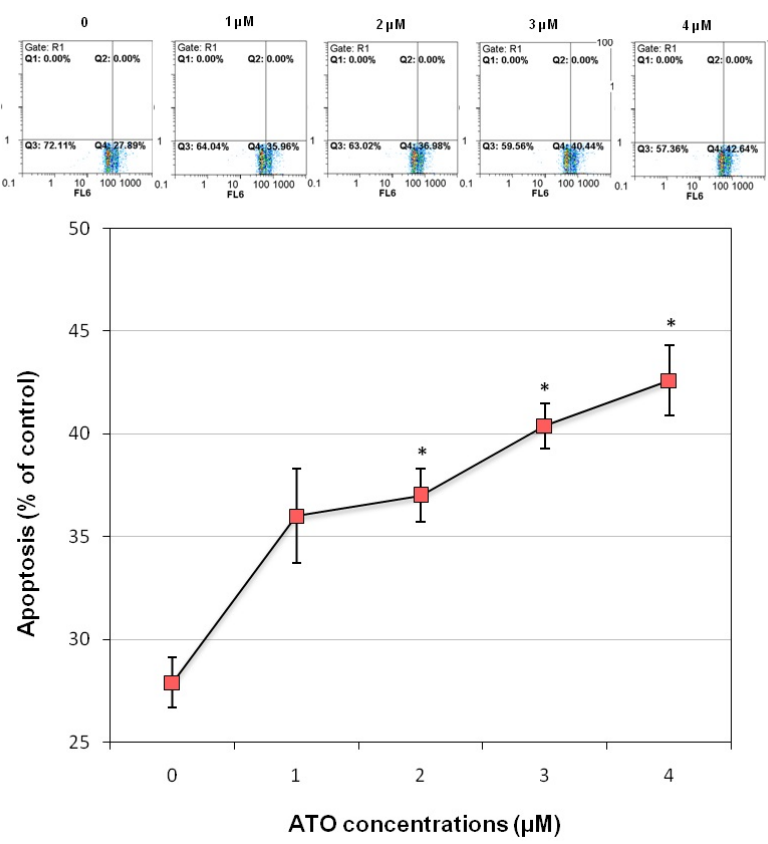

Figure 5. Effect of ATO on Programmed Cell Death in U87MG Cells Using a Double Staining kit with Hoechst 33342 and Propidium Iodide (PI). Hoechst 33342 stains the condensed chromatin in apoptotic cells more brightly than the chromatin in normal cells and PI is only permeate to dead cells (FL2: PI, FL6: Hoechst 33342). As shown in figure, ATO in concentration 1, 2, 3 and $4 \mu \mathrm{M}$ increases apoptosis in U87MG cells by $8.1 \%, 9.1 \%$ ( $<<0.05), 12.5 \%$ $(\mathrm{p}<0.05)$ and $14.7 \%(\mathrm{p}<0.05)$, respectively

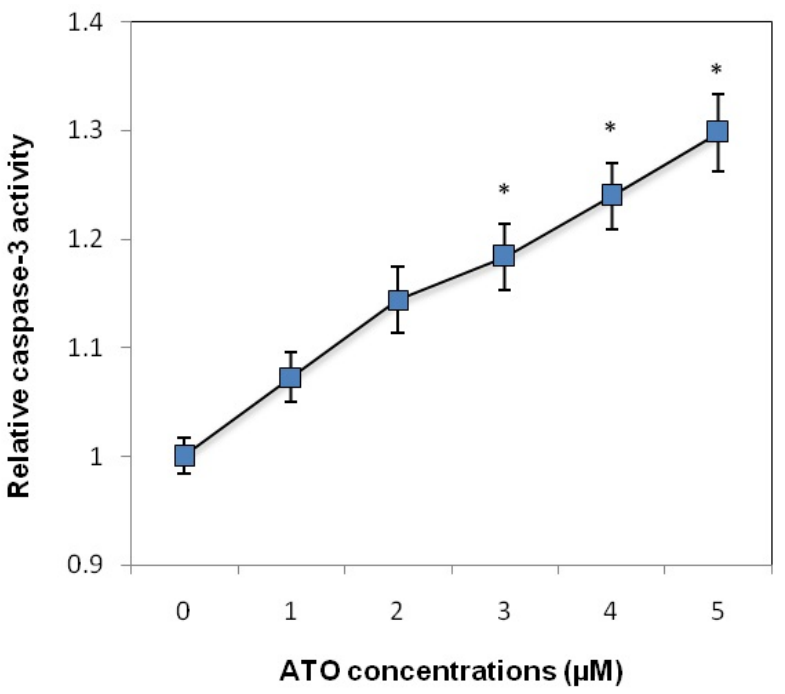

Figure 6. Stimulation of Caspase-3 Activity by ATO in U87MG Cells. ATO increased activity of caspase-3 in a concentration-dependent manner. Although this stimulation was not significant in case of 1 and 2 $\mu \mathrm{M}$ of ATO (7\% and $14.4 \%$ respectively), for higher concentrations this stimulation was statistically significant $(18.4 \%, 23.9 \%$ and $29.8 \%, \mathrm{p}<0.05)$ 
$\mathrm{As}_{2} \mathrm{O}_{3}$ Induces Apoptosis and Abrogates Proliferation and Invasivion of U87MG Glioblastoma Cells - NF- $\mathrm{\kappa B}$ Involvement

significantly decreased in this study, we decided to check the effect of ATO on transcriptional expression of IKK complex which consists of two catalytic subunits, IKK1 and IKK2, and a regulatory subunit called NEMO. Our results demonstrated that ATO at concentration 2,3, 4 and $5 \mu \mathrm{M}$ reduced gene expression of IKK2 by $36 \%$ $(\mathrm{p}<0.05), 37 \%(\mathrm{p}<0.05), 63 \%(\mathrm{p}<0.01)$ and $64 \%(\mathrm{p}<0.01)$ respectively (Figure 9A). On the other hand, ATO at concentration 3, 4 and $5 \mu \mathrm{M}$ stimulated gene expression of NEMO by $42 \%(\mathrm{p}<0.05), 69 \%(\mathrm{p}<0.05)$ and $106 \%$ $(\mathrm{p}<0.01)$ respectively; however, expression of IKK1 was not significantly changed after treatment with ATO (Figure 9A). ATO at concentration 1, 2 and $3 \mu \mathrm{M}$ almost didn't change expression of survivin, but in concentration 4 and $5 \mu \mathrm{M}$ diminished its expression to $32 \%(\mathrm{p}<0.01)$ and 23\% ( $<<0.01)$, respectively (Figure 9A). Expression of c-Myc was also significantly impeded at concentrations 2, 3, 4 and $5 \mu \mathrm{M}$ to $63 \%$ (p<0.05), $40 \%(\mathrm{p}<0.05), 25 \%$ $(\mathrm{p}<0.01)$ and $21 \%(\mathrm{p}<0.01)$ respectively, compared to control (Figure 9A). In addition, ATO down-regulated expression of hTERT in a dose-dependent manner. These observations are monitoring that the down-regulation of c-Myc and hTERT by ATO is coupled with inhibition of telomerase. The amount of decrease in expression of hTERT after treatment with $1,2,3,4$ and $5 \mu \mathrm{M}$ of ATO was 5\%, 32\% (p<0.05) 66\% (p<0.01), $89(\mathrm{p}<0.01)$ and $92 \%(\mathrm{p}<0.001)$ respectively (Figure $9 \mathrm{~A})$.

ATO down-regulates expression of Bfl-1 and up-regulates expression of caspase-3, p21 and $\mathrm{Bax} / \mathrm{Bcl}-2$ expression ratio

Regarding the fact that ATO is well-known for its stimulatory effect on apoptosis, it is expected to induce

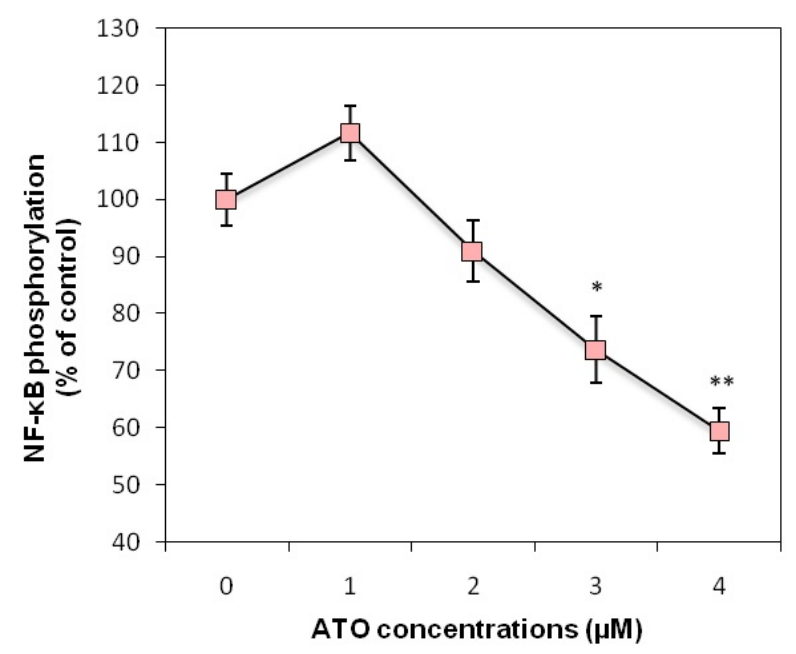

Figure 7. Effect of ATO on NF- $x$ B Phosphorylation in U87MG Cells. The phosphorylation of NF- $x \mathrm{~B}$, which is proportional to its activity, was measured by Cellular Activation of Signaling ELISA kit as described in section materials and methods. The phosphorylation was not significantly changed after $48 \mathrm{~h}$ treatment with concentrations 1 and $2 \mu \mathrm{M}$ of ATO (11.6\% increase and $9.1 \%$ decrease, respectively); however, ATO diminished the activity of NF- $x$ B by $26.3 \% \mathrm{p}<0.05)$ and $40.5 \%$ $(\mathrm{p}<0.01)$ at concentrations 3 and $4 \mu \mathrm{M}$, respectively. Values are given as mean \pm SD from three independent experiments $(*$ : $p$ $<0.05, * *: \mathrm{p}<0.01)$ expression of pro-apoptotic genes and down-regulate expression of anti-apoptotic genes. In line with this expectation we illustrated that ATO highly up-regulated transcriptional expression of Bax (2.75 fold increase at concentration $2 \mu \mathrm{M}, \mathrm{p}<0.01)$ and also increased mRNA expression of caspase- 3 which is in parallel with ATO effect on activity of this proapoptotic gene (Figure 9B). On the other hand, although ATO didn't have any significant effect on transcriptional expression of Bcl-2, the $\mathrm{Bax} / \mathrm{Bc}-2$ expression ratio was increased in a dosedependent manner (Figure 9B). ATO also significantly diminished transcriptional expression of Bfl-1, which is an anti-apoptotic Bcl-2 family member. However no significant effect was seen on Bcl-xl. Intriguingly ATO at concentrations $1,2,3,4$ and $5 \mu \mathrm{M}$ increased expression of p21 mRNA by 1.8 fold ( $<<0.05), 2.6$ fold $(\mathrm{p}<0.05), 2.8$ fold $(\mathrm{p}<0.05), 3.3$ fold $(\mathrm{p}<0.01)$ and 3.9 fold $(\mathrm{p}<0.001)$ respectively (Figure 9B).

\section{ATO down-regulates transcription of invasion-related genes}

After performing cell adhesion assay and gelatin zymography which showed that ATO could suppress cell invasion (Figure 2) and also activity of MMP-2 and MMP-9 (Figure 3) respectively, we decided to appraise the effect of ATO on transcriptional expression of invasionrelated genes in U87MG glioblastoma cell line. The results demonstrate that in line with the decrease in activity of MMP-2 and MMP-9, treatment of the U87MG cells

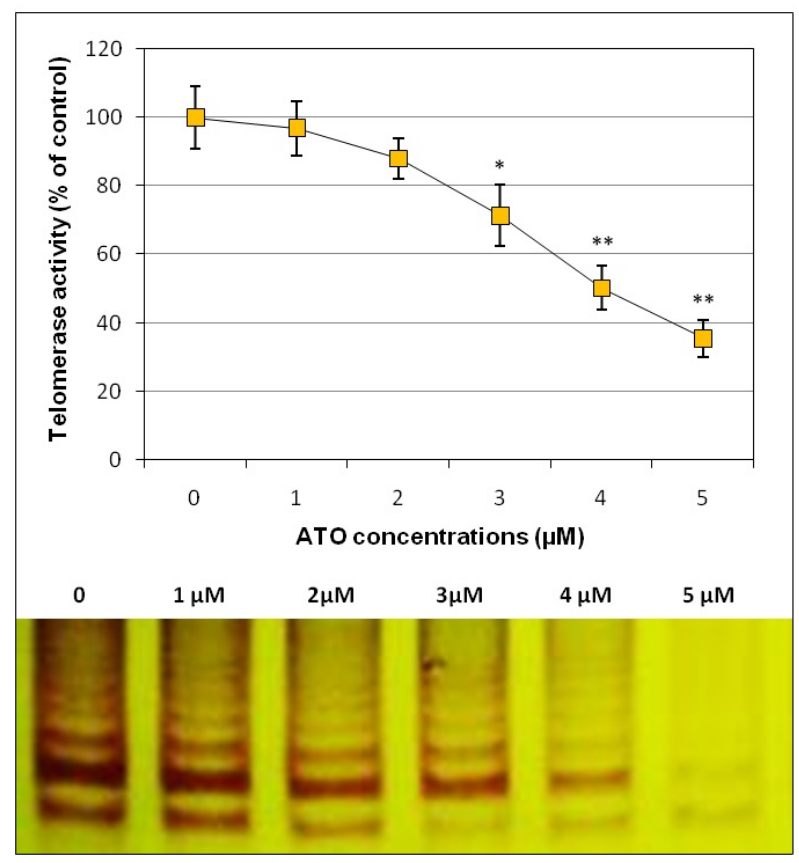

Figure 8. Inhibition of Telomerase Activity by ATO in U87MG Cells. The U87MG cells were treated with ATO and after $48 \mathrm{~h}$, cells were collected and telomerase activity was measured by performing PCR-based TRAP assay. TRAP reaction products were resolved by gel electrophoresis and then analyzed by densitometry. As shown in figure, ATO at concentrations 1 , $2,3,4$ and $\mu \mathrm{M}$ reduced the enzymatic activity of telomerase to $96.8 \%, 87.9 \%, 71.33 \%(\mathrm{p}<0.05), 50.2 \%(\mathrm{p}<0.01)$ and $35.44 \%$ $(\mathrm{p}<0.01)$, respectively. Values are given as mean \pm SD of three independent repetitions $(*: \mathrm{p}<0.05, * *: \mathrm{p}<0.01)$ 

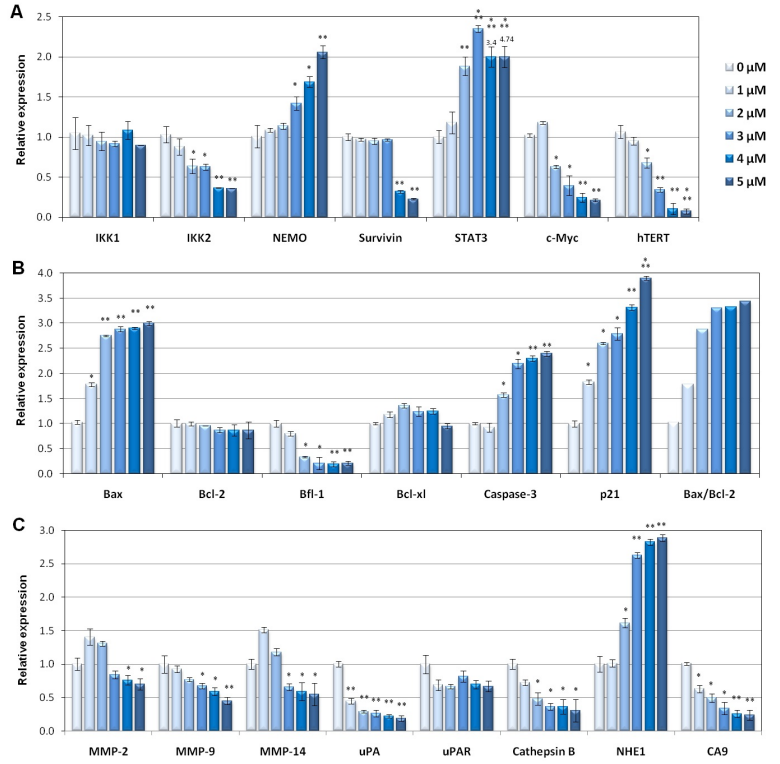

Figure 9. Effect of ATO on Transcriptional Expression of Proteins Involved in Survival, Apoptosis and Invasion of Glioblastoma Cells, Measured by Real-time PCR. (A) Transcriptional expression of IKK1, IKK2, NEMO (NF- $x$ B regulators), survivin, STAT3, c-Myc, hTERT in U87MG cell line, after treatment with ATO for $48 \mathrm{~h}$. (B) Evaluation of ATO on apoptosis-mediated genes in U87MG cells. (C) Effect of ATO on genes involved in invasion and media $\mathrm{pH}$ change in U87MG cells. Data are shown as fold change in relative expression compared with HPRT1 on the basis of comparative $\mathrm{Ct}$ $(2-\Delta \Delta \mathrm{Ct})$ method. Values are shown as mean $\pm \mathrm{SD}$. Statistically different values of $*$ : $p<0.05, * *: \mathrm{p}<0.01$ and $* * *$ : $\mathrm{p}<0.001$ are determined compared with the control

with higher concentrations of ATO results in a decrease in transcription of these two genes and also their related protein, MMP-14, which are involved in the invasion of glioblastoma (Figure 9C). ATO at concentrations 4 and 5 $\mu \mathrm{M}$ decreased the expression of MMP- 2 by $24 \%(\mathrm{p}<0.05)$ and $30 \%(\mathrm{p}<0.05)$; Moreover, ATO at concentrations 3, 4 and $5 \mu \mathrm{M}$ reduced expression of MMP-9 by $33 \%(\mathrm{p}<0.05)$, $41 \%(\mathrm{p}<0.05)$ and $55 \%(\mathrm{p}<0.01)$ and also diminished expression of MMP-14 by $34 \%(\mathrm{p}<0.05), 42 \%(\mathrm{p}<0.05)$ and $45 \%(\mathrm{p}<0.05)$, respectively (Figure $9 \mathrm{C})$. In addition, ATO had a concentration-dependent inhibitory effect on expression of cathepsin B $(\mathrm{p}<0.05)$ (Figure 9C) which is concomitant with the observation that ATO inhibits proteolytic activity of cathepsin B (see Figure 4) ATO also dose-dependently inhibited transcription of $\mathrm{uPA}(\mathrm{p}<0.01)$, but not its receptor, uPAR. Thus it may be intuitive that ATO possibly inhibits invasion of U87MG cell line through down-regulation of MMP-2, MMP-9, catehpsin B and probably uPA and MMP-14. On the other hand, tumor cells have acidic interstitial extracellular $\mathrm{pH}$ values. The acidic extracellular environment has role in driving the protease-mediated digestion and the remodeling of the extracellular matrix. In this regard, we evaluated effect of ATO on mRNA expression of $\mathrm{Na}+\mathrm{H}+$ exchanger (NHE1) and carbonic anhydrase IX (CA9), which are two important mediators for the cancer cell microenvironment acidification, and their overexpressions are reported to be correlated with glioma invasion and metastasis (McLean

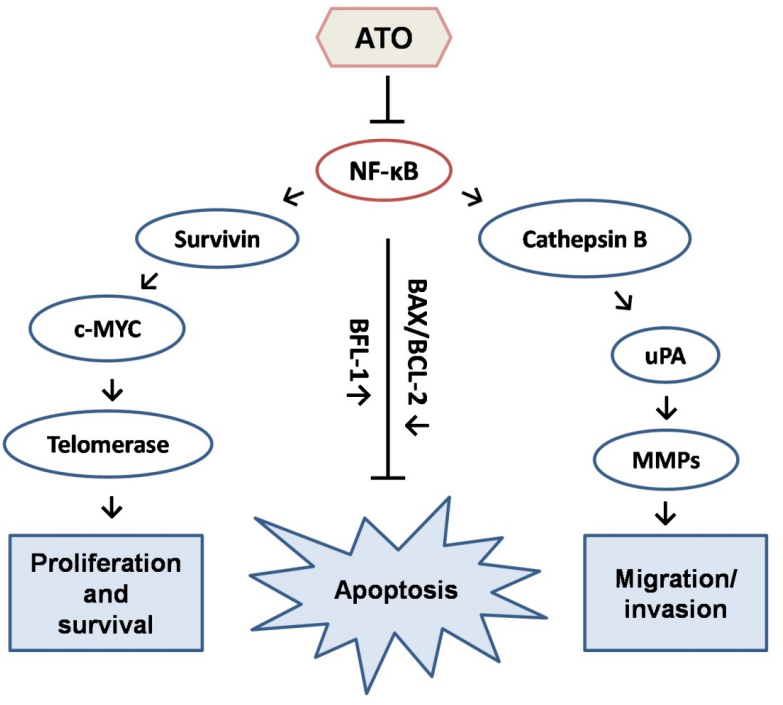

Figure 10. A Holistic View of the Role of ATO Versus NF- $x$ B in U87MG Glioblastoma Cell Line. The oncogenic effect of NF- $x \mathrm{~B}$ in glioblastoma is mediated by regulation of many molecules involved in proliferation and survival, cell invasion and migration and evasion from apoptosis. In glioblastoma, NF- $x \mathrm{~B}$ increases proliferation and inhibits apoptosis through different molecules including downregulation of Bax and upregulation of survivin which in turn stimulates transcription and activity of telomerase. It has also been very well established that NF- $x \mathrm{~B}$ could stimulate activation of uPA through lysosomal protease cathepsin $\mathrm{B}$, which then activate matrix metalloproteinases as direct mediators of ECM remodeling and results in cell migration/invasion. ATO is an anticancer drug that suppresses survival, immortalization and invasion of various tumor cells through various action mechanisms. In this study, we investigated some of the molecular targets of ATO which are known as common targets of NF- $\varkappa \mathrm{B}$. Importantly, we observed that ATO significantly inhibited phosphorylation of $\mathrm{NF}-x \mathrm{~B}$ and also diminished gene expression of IKK2, suggesting the inhibitory effect of ATO on canonical NF- $x$ B pathway. Further, we observed that ATO effected on the transcriptional level of genes involved in survival (Bax, c-MYC and Survivin), immortalization (hTERT) and invasion and metastasis (cathepsin B, uPA, MMP-2 and MMP-9, MMP-14) in U87MG cell line. Moreover, ATO suppressed enzymatic activity of telomerase, cathepsin B, MMP-2 and MMP-9 which supports our observation that ATO suppresses migration of U87MG cells

et al., 2000; Yoo et al., 2010). Our results demonstrate that ATO dose-dependently inhibits expression of CA9. However, expression of NHE1 was unexpectedly upregulated (Figure 9C).

\section{Discussion}

A plethora of studies reports that ATO impedes cell proliferation and stimulates apoptosis in human cancers (Siu et al., 2002; Vuky et al., 2002; Yu et al., 2007; Morales et al., 2008; Pettersson et al., 2009; Liu et al., 2012). Although ATO influences numerous signaling pathways, the mechanisms through which programmed cell demise is induced by ATO in GBM remains to be elucidated. The knowledge of the detailed mechanisms of ATO-induced toxicity may be helpful in designing more effective therapies for this highly invasive human cancer. 
The current study demonstrated that ATO stimulated the viability and proliferation of U87MG cells and revealed a significant increase in apoptosis.

$\mathrm{NF}-\varkappa \mathrm{B}$ is a pivotal molecule involved in tumor initiation and progression in various types of human cancers as well as GBM (Zanotto-Filho et al., 2011; Westhoff et al., 2013). In fact, sustained activation of NF- $x \mathrm{~B}$ in glioblastoma has been reported (Nagai et al., 2002). Furthermore, it has been reported that suppression of NF- $x \mathrm{~B}$ through overexpression of its inhibitor, I $x \mathrm{~B}$ results in alleviation of U87MG invasion (Chintala et al., 1998). Thus, NF- $\kappa \mathrm{B}$ plays a crucial role in tumor invasion and infiltration in glioblastoma. In line with the previous studies we demonstrated here that ATO significantly inhibits activity of NF- $\mathrm{BB}$ (Figure 7). NF$\kappa \mathrm{B}$ activation is regulated through phosphorylation of

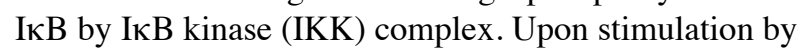
stimuli, IкBs are phosphorylated by IKK complex which results in releasing the active $N F-\kappa B$, which could be translocated into the nucleus and regulate the expression of the target genes (Baud and Karin, 2009). IKK complex consists of two catalytic subunits, IKK1 (IKK $\alpha)$ and IKK2 (IKK $\beta)$, and a regulatory protein called NEMO. In addition, it has been demonstrated that IKK 2 and NEMO are mandatory for activation of canonical NF- $\kappa B$ pathway, but the activation of alternative $\mathrm{NF}-\kappa \mathrm{B}$ pathway is dependent on IKK1 (Pomerantz and Baltimore, 2002; Derudder et al., 2003). Then we assessed effect of ATO on the transcriptional expression of IKK1, IKK2, and NEMO in U87MG cells. The results illustrated that ATO dose-dependently diminished transcription of IKK2, but had no effect on transcription level of IKK1 (Figure 9A). Thus, it may be possible that ATO inhibits canonical NF$\kappa \mathrm{B}$ pathway. Moreover, in contrast to our expectation, the results demonstrated that ATO not only had no inhibitory effect on NEMO transcription level, but also significantly up-regulated its mRNA level. As mentioned above, IKK1 and IKK2 are catalytic subunits of and both are involved directly in the NF-KB activation. However, NEMO is a regulatory subunit which exerts its function through interactions with the catalytic subunits more than direct actions.

Caspase- 3 is a member of the cysteine-aspartic acid protease (caspase) family which exist as inactive proenzymes that undergo proteolytic processing at conserved aspartic residues to produce two subunits, that dimerize to form the active enzyme (Harrington et al., 2008). This protein could be processed and activated through both extrinsic (death ligands) and intrinsic (mitochondrial) pathways. Cytochrome $\mathrm{c}$ from the mitochondria in combination with caspase-9, Apaf-1, and ATP process procaspase-3 (Porter and Janicke, 1999). Given that caspase- 3 recognizes and cleaves specific conserved tetrapeptide motifs which exist in the amino acid sequence of NF-кB p65 subunit (Nicholson et al., 1995), it has been experimentally demonstrated that NF-кB-medaited inhibition of apoptosis in cancer cells might be abrogated through caspase-3-mediated cleavage of p65 (Kang et al., 2001). In the current study we show that ATO dose-dependently up-regulated transcription and proteolytic activity of caspase-3. Thus pro-apoptotic effect of ATO on U87MG cells may be through up-regulation of caspase-3, and subsequently caspase-3-mediated inhibition of NF- $\mathrm{KB}$. Intriguingly it has been reported that in isolated GBM cells and long-term-cultured U87MG cells, caspase-3 levels are not sufficient to stimulate apoptosis, but might contribute to the motility (Zarnescu et al., 2008). In addition, the protein expression of caspase-3 in GBM samples is lower compared to the expression of Bcl-2, suggesting that anti-apoptotic forces in GBMs are higher than the pro-apoptotic ones (Tirapelli et al., 2010). With respect to our observation that ATO up-regulates mRNA expression and activity of caspase-3, and that ATO didn't change expression of Bcl-2 (Figure 9B), it might be possible that ATO may change $\mathrm{Bcl}-2 /$ caspase- 3 ratio in favor of pro-apoptotic caspase-3.

It has been delineated that NF- $\mathrm{KB}$-mediated apoptosis is triggered through down-regulation of anti-apoptotic proteins such as Bcl-2 family members of proteins as well as up-regulation of pro-apoptotic proteins e.g. bax and bad (Shou et al., 2002; Cao et al., 2013). In this regard, we evaluated expression of some downstream mediators of NF- $x$ B-mediated apoptosis in ATO-treated U87MG cells. We observed that ATO highly up-regulated transcription of Bax. Moreover, although ATO didn't change expression of Bcl-2, Bax/bcl-2 ratio was dose-dependently elevated. In addition, ATO highly diminished expression of Bfl1 which is an anti-apoptotic Bcl-2 family member of proteins. Thus ATO may induce apoptosis in U87MG cells possibly through NF- $\mathrm{BB}$-mediated down-regulation of anti-apoptotic genes and up-regulation of pro-apoptotic genes such as Bax and caspase-3 (Figure 9B and 10).

P21 is a protein mostly known for its roles in cell cycle control. P21 halts the cell cycle progression into and through $\mathrm{S}$ phase by inhibition of cyclin $\mathrm{E} / \mathrm{cdk} 2$. Moreover, p21 inhibits cyclin A/cdk2 and cyclin A/cdk1 thereby inhibits progression through $\mathrm{S}$ phase and into G2, respectively (Abbas and Dutta, 2009). Although best known for its effect on cell cycle, p21 has a paradoxical pro-apoptotic activity. In fact, it may be expected that P21 might protects cells from apoptosis because an active cell cycle is required to trigger apoptosis. (Abbas and Dutta, 2009). However, the anti-apoptotic effect of p21 is counteracted by various mechanisms including transcriptional repression of CDKN1A and the selective activation of pro-apoptotic genes (Kaneuchi et al., 1999; Samuels-Lev et al., 2001). In line with these observations, we demonstrated that ATO highly up-regulates mRNA expression of $\mathrm{p} 21$. In fact $\mathrm{p} 21$ might stimulate apoptosis through both p53-dependent and p53-independent mechanisms specially up-regulation of the pro-apoptotic protein Bax (Gartel, 2005), which is in parallel with our observation regarding ATO-mediated up-regulation of Bax (Figure 9B). Thus it may be possible that $\mathrm{p} 21$ is involved in apoptosis caused by ATO in U87MG cells.

Survivin is an important member of inhibitor of apoptosis protein (IAP) family (Ryan et al., 2009) and involved in various hallmarks of cancer including cell proliferation, angiogenesis, metastasis and evasion from apoptosis (Conway et al., 2003; Li, 2005). The expression of survivin is regulated through different mechanisms which are mainly classified as cell-cycle-dependent 
and non-cell cycle-dependent mechanisms (Pennati et al., 2008). The later mechanism drives survivin gene transcription independent of mitosis and involves signal transducer and activator of transcription 3 (STAT3) (Gritsko et al., 2006), co-stimulatory messages e.g. NF- $x$ B (Mitsiades et al., 2002) and other pleiotropic signaling mechanisms (Pennati et al., 2008). In this study, we observed that higher concentrations of ATO inhibit expression of survivin, but expression of STAT3 was highly increased in ATO-treated U87MG cells (Figure 9A). Thus it may be possible that inhibitory effect of ATO on transcription of survivin is possibly independent of STAT3. Regarding the previous reports with respect to stimulatory effect of NF- $\mathrm{KB}$ on survivin (Mitsiades et al., 2002), it may be possible that ATO-induced inhibition of NF-кB in U87MG cells may result in decreased expression of surviving (Figure 10).

It has been reported that survivin stimulates human telomerase activity which in turn allows short telomeres to be stabilized at a constant length and thereby provides cells with the ability to proliferate indefinitely (Endoh et al., 2005a). The survivin-dependent induction of telomerase mainly occurs through stimulatory effect of c-Myc (Cerni, 2000; Wojtyla et al., 2011). C-Myc is a transcription factor which regulates transcription of a plethora of genes involved in cell proliferation including hTERT, the catalytic subunit of telomerase. We subsequently observed that ATO inhibited transcriptional expression of c-Myc, and also dose-dependently suppressed transcription of hTERT and also reverse-transcriptional activity of telomerase. Thus, it may be reasonable to conclude that ATO possibly limits proliferation of U87MG cells through suppression of NF- $\kappa \mathrm{B}$-mediated survivin-dependent telomerase activity (Figure 10).

The major obstacle in the treatment of GBM is thought to be driven by the high activation of proteases which lead to degradation of ECM (Nakada et al., 2007). Thus it seems of paramount importance to explore therapeutic interventions to quell proteolytic pathways which degrade ECM and subsequently debilitate tumor invasion and infiltration. In this regard, $\mathrm{NF}-x \mathrm{~B}$ targets have the most known roles in glioma invasion. Urokinase plasminogen activator (uPA), which is activated by lysosomal protease cathepsin $\mathrm{B}$, has been thought to play a cardinal role in invasion of the tumor cells by ECM remodeling through activation of respective proteases (Guo et al., 2002). It has been reported that elevated levels of uPA is highly correlated with poor prognosis in glioblastoma (Zhang et al., 2000). Moreover, transfection of SNB19 glioma cells with antisense $\mathrm{UPA}$ vectors resulted in debilitated invasion and weakened migration in these cells (Mohanam et al., 2001). Thus uPA has a crucial role in glioma invasion. Our results demonstrated that ATO dose-dependently suppresses proteolytic activity (Figure 4) and transcription of cathepsin B and also negatively regulates transcription of uPA in a concentration-dependent manner (Figure 9C). In addition, augmented levels of uPA receptor (UPAR) has been reported to contribute to glioblastoma invasion (Mohanam et al., 1993), but our results demonstrated that ATO didn't pose any significant inhibitory effect on uPAR transcription.
The determinant roles of NF- $\kappa \mathrm{B}$ in triggering cathepsindependent and UPA-mediated tumor invasion have been thought to be through the induction of MMP-2 and MMP-9 (Baud and Karin, 2009). Immunohistochemical studies have shown that expression of MMP-2 and MMP9 is significantly elevated with the degree of glioma malignancy (Wang et al., 2003). Moreover, blockage of glioma invasion by inhibition of MMP-2 and MMP-9 confirm the role of these proteases in gliomas (Blázquez et al., 2008; Sun et al., 2013). In our previous work, we have shown that suppression of cathepsin B- and nuclear factor kappa B-mediated MMP-9 diminishes neoplastic features of U87MG cell line (Momeny et al., 2010a). Taken together, the previous studies have highlighted the pivotal roles of MMP-2 and MMP-9 in glioma invasion and infiltration and suggest that they would be as promising pharmaceutics to castrate cell dissemination. In line with those studies, our results demonstrate that ATO suppressed gelatinolytic activity of MMP-2 and MMP-9 in U87MG cells in a dose-dependent manner (Figure 3) and concomitantly diminished transcriptional expression of these two navigators of glioma cell invasion (Figure 9C and 10). Moreover, MMP-2 activity is concentrated at the cell surface by membrane-type 1 MMP (MT1-MMP, MMP14) (Ware et al., 2003) which is up-regulated in human gliomas and presumably facilitate ECM destruction (Ware et al., 2003). Concordantly, we demonstrated that ATO also negatively regulates transcription of MT1-MMP at higher concentrations (Figure 9C).

It has been illustrated that malignant gliomas have alkaline intracellular $\mathrm{pH}$ (pHi) and acidic extracellular $\mathrm{pH}$ (pHe) values. Regarding the fact that acidic $\mathrm{pHe}$ limits the availability of HCO3- and subsequently reduces $\mathrm{HCO} 3-$ -dependent buffering system, it has been suggested that malignant gliomas require other $\mathrm{H}+$ buffering pathways such as the type $1 \mathrm{Na}+\mathrm{H}+$ exchanger (NHE1) and carbonic anhydrase IX (CA9) (McLean et al., 2000; Yoo et al., 2010). In line with these mechanism, it has been reported that expression of CA9 is directly correlated with increasing histological grade and poor survival in gliomas (Yoo et al., 2010), thus may provide a promising approach for development of tumor-selective therapies. In line with these findings, we observed that ATO impeded transcriptional expression of CA9 in a dosedependent manner (Figure 9C). Regarding that the acidic extracellular environment has role in driving the proteasemediated digestion and the remodeling of the extracellular matrix, it may be possible that one mechanism through which ATO debilitates glioma invasion, is possibly extracellular alkalization. Moreover, it has been reported that NHE1 activity is increased in gliomas (McLean et al., 2000); however, in this work, we demonstrate that ATO not only doesn't inhibit transcription of NHE1, but also significantly stimulates its expression in U87MG cells (Figure 9C). Considering that ATO alkalizes media pH in glioma (Dizaji et al., 2012), and that it has no inhibitory effect on expression of NHE1 in U87MG cells, it may be possible that ATO-dependent alkalization of gliomas may be independent of NHE1 and is possibly through other molecules e.g. CA9 or $\mathrm{Na}+$-independent $\mathrm{HCO} 3-/ \mathrm{Cl}$ - exchangers and $\mathrm{H}+/$ lactate cotransporter 

(monocarboxylate transporter, MCT) (Madshus, 1988).

Collectively, this study was the first evaluation appraising effect of ATO on proliferation, apoptosis and invasion of U87MG, a highly invasive grade IV-derived glioma cell line. It seems that NF- $\mathrm{KB}$ has a key role in ATO-mediated responses. We suggest that ATO could inhibit proliferation of U87MG cells possibly through inhibition of NF- $x$ B-mediated survivin-dependent telomerase activity and also could induce apoptosis in U87MG cells possibly through NF- $x \mathrm{~B}$-dependent proapototic mechanisms (Figure 10). Moreover, ATO could inhibit invasion of U87-MG cell line possibly through inhibition of NF- $\mathrm{BB}$ - and cathepsin B-mediated activation of UPA and the related MMPs (Figure 10). However, more studies should be done to exactly address detailed mechanisms through which ATO incapacitate proliferation and invasion of U87MG cells.

\section{Acknowledgements}

This study was supported by Hematology, Oncology and Stem Cell Transplantation Research Center, Tehran University of Medical Sciences, Tehran, Iran.

\section{References}

Abbas T, Dutta A (2009).p21 in cancer: intricate networks and multiple activities. Nat Rev Cancer, 9, 400-14.

Baud V, Karin M (2009). Is NF-kappaB a good target for cancer therapy? Hopes and pitfalls. Nat Rev Drug Discov, 8, 33-40.

Bharti AC, Donato N, Singh S, et al (2003). Curcumin (diferuloylmethane) down-regulates the constitutive activation of nuclear factor- $\chi \mathrm{B}$ and $\mathrm{I} \varkappa \mathrm{B} \alpha$ kinase in human multiple myeloma cells, leading to suppression of proliferation and induction of apoptosis. Blood, 101, 1053-62.

Blázquez C, Salazar M, Carracedo A, et al (2008). Cannabinoids Inhibit Glioma Cell Invasion by Down-regulating Matrix Metalloproteinase-2 Expression. Cancer Res, 68, 1945-52.

Cao JP, Niu HY, Wang HJ, et al (2013). NF- $x B$ p65/p52 plays a role in GDNF up-regulating Bcl-2 and Bcl-w expression in 6-OHDA-induced apoptosis of MN9D cell. Int $J$ Neuroscience, 123, 705-10.

Cerni C (2000). Telomeres, telomerase, and myc. An update. Mutat Res, 462, 31-47.

Chintala SK, Sawaya R, Aggarwal BB, et al (1998). Induction of matrix metalloproteinase-9 requires a polymerized actin cytoskeleton in human malignant glioma cells. J Biol Chem, 273, 13545-51.

Cohen KJ, Gibbs IC, Fisher PG, et al (2013). A phase I trial of arsenic trioxide chemoradiotherapy for infiltrating astrocytomas of childhood. Neuro Oncol, 15, 783-7.

Conway EM, Zwerts F, Van Eygen V, et al (2003). Survivindependent angiogenesis in ischemic brain: molecular mechanisms of hypoxia-induced up-regulation. Am J Pathol, 163, 935-46.

Derudder E, Dejardin E, Pritchard LL, et al (2003). RelB/p50 dimers are differentially regulated by tumor necrosis factoralpha and lymphotoxin-beta receptor activation: critical roles for p100. J Biol Chem, 278, 23278-84.

Dizaji MZ, Malehmir M, Ghavamzadeh A, et al (2012). Synergistic effects of arsenic trioxide and silibinin on apoptosis and invasion in human glioblastoma U87MG cell line. Neurochem Res, 37, 370-80.
Endoh T, Tsuji N, Asanuma K, et al (2005a). Survivin enhances telomerase activity via up-regulation of specificity protein 1and c-Myc-mediated human telomerase reverse transcriptase gene transcription. Experimental Cell Res, 305, 300-11.

Endoh T, Tsuji N, Asanuma K, et al (2005b). Survivin enhances telomerase activity via up-regulation of specificity protein 1and c-Myc-mediated human telomerase reverse transcriptase gene transcription. Exp Cell Res, 305, 300-11.

Gartel AL (2005). The conflicting roles of the cdk inhibitor p21(CIP1/WAF1) in apoptosis. Leuk Res, 29, 1237-8.

Gritsko T, Williams A, Turkson J, et al (2006). Persistent activation of stat 3 signaling induces survivin gene expression and confers resistance to apoptosis in human breast cancer cells. Clin Cancer Res, 12, 11-9.

Guo M, Mathieu PA, Linebaugh B, et al (2002). Phorbol ester activation of a proteolytic cascade capable of activating latent transforming growth factor-betaL a process initiated by the exocytosis of cathepsin B. J Biol Chem, 277, 14829-37.

Harrington HA, Ho KL, Ghosh S, et al (2008). Construction and analysis of a modular model of caspase activation in apoptosis. Theor Biol Med Model, 5, 26.

Hawkes S, Li H, Taniguchi G (2010). Zymography and Reverse Zymography for Detecting MMPs and TIMPs. Methods Mol Biol, 257-69.

Jing Y, Dai J, Chalmers-Redman RM, et al (1999). Arsenic trioxide selectively induces acute promyelocytic leukemia cell apoptosis via a hydrogen peroxide-dependent pathway. Blood, 94, 2102-11.

Kaneuchi M, Yamashita T, Shindoh M, et al (1999). Induction of apoptosis by the p53-273L (Arg --> Leu) mutant in HSC3 cells without transactivation of $\mathrm{p} 21 \mathrm{Waf} 1 / \mathrm{Cip} 1 / \mathrm{Sdi} 1$ and bax. Mol Carcinog, 26, 44-52.

Kang KH, Lee KH, Kim MY, et al (2001). Caspase-3-mediated cleavage of the NF-kappa B subunit p65 at the $\mathrm{NH} 2$ terminus potentiates naphthoquinone analog-induced apoptosis. J Biol Chem, 276, 24638-44.

Li F (2005). Role of survivin and its splice variants in tumorigenesis. Br J Cancer, 92, 212-6.

Liu W, Gong Y, Li H, et al (2012). Arsenic Trioxide-Induced Growth Arrest of Breast Cancer MCF-7 Cells Involving FOXO3a and IkappaB Kinase beta Expression and Localization. Cancer Biother Radiopharm, 27, 504-12.

Lo Coco F, Diverio D, Falini B, et al (1999). Genetic diagnosis and molecular monitoring in the management of acute promyelocytic leukemia. Blood, 94, 12-22.

Madshus IH (1988). Regulation of intracellular $\mathrm{pH}$ in eukaryotic cells. Biochem J, 250, 1-8.

McLean LA, Roscoe J, Jørgensen NK, et al (2000). Malignant gliomas display altered $\mathrm{pH}$ regulation by NHE1 compared with nontransformed astrocytes. Am J Physiol Cell Physiol, 278, 676-88.

Miller WH Jr., Schipper HM, Lee JS, et al (2002). Mechanisms of action of arsenic trioxide. Cancer Res, 62, 3893-903.

Mitsiades CS, Mitsiades N, Poulaki V, et al (2002). Activation of NF-kappaB and upregulation of intracellular anti-apoptotic proteins via the IGF-1/Akt signaling in human multiple myeloma cells: therapeutic implications. Oncogene, 21, 5673-83.

Mohanam S, Jasti SL, Kondraganti SR, et al (2001). Stable transfection of urokinase-type plasminogen activator antisense construct modulates invasion of human glioblastoma cells. Clin Cancer Res, 7, 2519-26.

Mohanam S, Sawaya R, McCutcheon I, et al (1993). Modulation of in vitro invasion of human glioblastoma cells by urokinase-type plasminogen activator receptor antibody. Cancer Res, 53, 4143-7.

Momeny M, Malehmir M, Zakidizaji M, et al (2010a). Silibinin 
inhibits invasive properties of human glioblastoma U87MG cells through suppression of cathepsin B and nuclear factor kappa B-mediated induction of matrix metalloproteinase 9. Anticancer Drugs, 21, 252-60.

Momeny M, Zakidizaji M, Ghasemi R, et al (2010b). Arsenic trioxide induces apoptosis in NB-4, an acute promyelocytic leukemia cell line, through up-regulation of p73 via suppression of nuclear factor kappa B-mediated inhibition of p73 transcription and prevention of NF-kappaB-mediated induction of XIAP, cIAP2, BCL-XL and survivin. Med Oncol, 27, 833-42.

Morales AA, Gutman D, Lee KP, et al (2008). BH3-only proteins Noxa, Bmf, and Bim are necessary for arsenic trioxideinduced cell death in myeloma. Blood, 111, 5152-62.

Nagai S, Washiyama K, Kurimoto M, et al (2002). Aberrant nuclear factor-kappaB activity and its participation in the growth of human malignant astrocytoma. J Neurosurg, 96, 909-17.

Nakada M, Nakada S, Demuth T, et al (2007). Molecular targets of glioma invasion. Cell Mol Life Sci, 64, 458-78.

Nicholson DW, Ali A, Thornberry NA, et al (1995). Identification and inhibition of the ICE/CED-3 protease necessary for mammalian apoptosis. Nature, 376, 37-43.

Pennati M, Folini M, Zaffaroni N (2008). Targeting survivin in cancer therapy. Expert Opinion Therapeutic Targets, 12, 463-76.

Pettersson HM, Pietras A, Munksgaard Persson M, et al (2009). Arsenic trioxide is highly cytotoxic to small cell lung carcinoma cells. Mol Cancer Ther, 8, 160-70.

Pomerantz JL, Baltimore D (2002). Two pathways to NFkappaB. Mol Cell, 10, 693-5.

Porter AG, Janicke RU (1999). Emerging roles of caspase-3 in apoptosis. Cell Death Differ, 6, 99-104.

Rao JS (2003). Molecular mechanisms of glioma invasiveness: the role of proteases. Nature reviews. Cancer, 3, 489-501.

Ryan BM, O'Donovan N, Duffy MJ (2009). Survivin: A new target for anti-cancer therapy. Cancer Treat Rev, 35, 553-62.

Samuels-Lev Y, O'Connor DJ, Bergamaschi D, et al (2001). ASPP proteins specifically stimulate the apoptotic function of p53. Mol Cell, 8, 781-94.

Sanz MA, Fenaux P, Lo Coco F (2005). Arsenic trioxide in the treatment of acute promyelocytic leukemia. A review of current evidence. Haematologica, 90, 1231-5.

Shou Y, Li N, Li L, et al (2002). NF-kappaB-mediated upregulation of $\mathrm{Bcl}-\mathrm{X}(\mathrm{S})$ and $\mathrm{Bax}$ contributes to cytochrome c release in cyanide-induced apoptosis. J Neurochem, $\mathbf{8 1}$, 842-52.

Siu KP, Chan JY, Fung KP (2002). Effect of arsenic trioxide on human hepatocellular carcinoma HepG2 cells: inhibition of proliferation and induction of apoptosis. Life Sci, 71, 275-85.

Sun C, Wang Q, Zhou H, et al (2013). Antisense MMP-9 RNA inhibits malignant glioma cell growth in vitro and in vivo. Neuroscience Bulletin, 29, 83-93.

Tallman MS (2001). Arsenic trioxide: its role in acute promyelocytic leukemia and potential in other hematologic malignancies. Blood Rev, 15, 133-42.

Tirapelli LF, Bolini PH, Tirapelli DP, et al (2010). Caspase-3 and Bcl-2 expression in glioblastoma: an immunohistochemical study. Arq Neuropsiquiatr, 68, 603-7.

Vuky J, Yu R, Schwartz L, et al (2002). Phase II trial of arsenic trioxide in patients with metastatic renal cell carcinoma. Invest New Drugs, 20, 327-30.

Wang M, Wang T, Liu S, et al (2003). The expression of matrix metalloproteinase-2 and-9 in human gliomas of different pathological grades. Brain Tumor Pathol, 20, 65-72.

Ware ML, Berger MS, Binder DK (2003). Molecular biology of glioma tumorigenesis. Histol Histopathol, 18, 207-16.
Wei LH, Lai KP, Chen CA, et al (2005). Arsenic trioxide prevents radiation-enhanced tumor invasiveness and inhibits matrix metalloproteinase-9 through downregulation of nuclear factor kappaB. Oncogene, 24, 390-8.

Westhoff M-A, Zhou S, Nonnenmacher L, et al (2013). Inhibition of NF- $x$ B Signaling Ablates the Invasive Phenotype of Glioblastoma. Molecular Cancer Res.

Wojtyla A, Gladych M, Rubis B (2011). Human telomerase activity regulation. Mol Biol Rep, 38, 3339-49.

Yoo H, Sohn S, Nam BH, et al (2010). The expressions of carbonic anhydrase 9 and vascular endothelial growth factor in astrocytic tumors predict a poor prognosis. Int $J$ Mol Med, 26, 3-9.

Yu J, Qian H, LiY, et al (2007). Arsenic trioxide (As2O3) reduces the invasive and metastatic properties of cervical cancer cells in vitro and in vivo. Gynecol Oncol, 106, 400-6.

Zanotto-Filho A, Braganhol E, Schroder R, et al (2011). NFkappaB inhibitors induce cell death in glioblastomas. Biochem Pharmacol, 81, 412-24.

Zarnescu O, Brehar FM, Chivu M, et al (2008). Immunohistochemical localization of caspase-3, caspase-9 and Bax in U87 glioblastoma xenografts. J Mol Histol, 39, 561-9.

Zhang X, Bu XY, Zhen HN, et al (2000). Expression and localisation of urokinase-type plasminogen activator gene in gliomas. J Clin Neurosci, 7, 116-9. 